\title{
Assessment of carotenoids in pumpkins after different home cooking conditions
}

\author{
Lucia Maria Jaeger de CARVALHO ${ }^{1 *}$, Lara de Azevedo Sarmet Moreira SMIDERLE ${ }^{1}$,
} José Luiz Viana de CARVALHO², Flavio de Souza Neves CARDOSO ${ }^{1}$, Maria Gabriela Bello KOBLITZ ${ }^{3}$

\begin{abstract}
Carotenoids have antioxidant activity, but few are converted by the body into retinol, the active form of vitamin A. Among the 600 carotenoids with pro-vitamin A activity, the most common are $\alpha$ - and $\beta$-carotene. These carotenoids are susceptible to degradation (e.g., isomerization and oxidation) during cooking. The aim of this study was to assess the total carotenoid, $\alpha$ - and $\beta$-carotene, and 9 and 13-Z- $\beta$-carotene isomer contents in C. moschata after different cooking processes. The raw pumpkin samples contained 236.10, 172.20, 39.95, 3.64 and $0.8610 \mu \mathrm{g} . \mathrm{g}^{-1}$ of total carotenoids, $\beta$-carotene, $\alpha$-carotene, 13 -cis- $\beta$-carotene, and 9-Z- $\beta$-carotene, respectively. The samples cooked in boiling water contained $258.50,184.80,43.97,6.80$, and $0.77 \mu \mathrm{g} . \mathrm{g}^{-1}$ of total carotenoids, $\beta$-carotene, $\alpha$-carotene, $13-Z-\beta$-carotene, and $9-Z$ - $\beta$-carotene, respectively. The steamed samples contained $280.77,202.00,47.09,8.23$, and $1.247 \mu \mathrm{g} . \mathrm{g}^{-1}$ of total carotenoids, $\beta$-carotene, $\alpha$-carotene, $13-Z$ - $\beta$-carotene, and 9 - $Z$ - $\beta$-carotene, respectively. The samples cooked with added sugar contained $259.90,168.80,45.68,8.31$, and $2.03 \mu \mathrm{g} \cdot \mathrm{g}^{-1}$ of total carotenoid, $\beta$-carotene, $\alpha$-carotene, 13-Z- $\beta$-carotene, and 9-Z- $\beta$-carotene, respectively. These results are promising considering that $E$ $\beta$-carotene has $100 \%$ pro-vitamin A activity. The total carotenoid and carotenoid isomers increased after the cooking methods, most likely as a result of a higher availability induced by the cooking processes.
\end{abstract}

Keywords: pro-vitamin A; carotenoids; pumpkin landraces; C. moschata; pumpkin meals; $\alpha$-carotene; $\beta$-carotene; $\beta$-carotene isomers.

\section{Introduction}

A large number of pumpkin varieties, each of which containing different amounts of carotenoids, are cultivated worldwide (Juna et al., 2006). In Brazil, C. moschata cultivars are known to contain high amount of $\alpha$ - and $\beta$-carotene. $\beta$-carotene has $100 \%$ pro-vitamin A activity, and $\alpha$-carotene has approximately 53\% pro-vitamin A activity (MínguezMosquera et al., 2002; Silva \& Mercadante, 2002; Boiteux et al, 2007; Rodriguez-Amaya et al., 2008).

High contents of total carotenoids $\left(2120 \mu \mathrm{g} .100 \mathrm{~g}^{-1}\right)$ and $\beta$-carotene $\left(1180 \mu \mathrm{g} .100 \mathrm{~g}^{-1}\right)$ have been found in C. maxima. However, the highest concentration of total carotenoids (47 $\mu \mathrm{g}$. $\mathrm{g}^{-1}$ of $E$ - $\alpha$-carotene and $235 \mu \mathrm{g} . \mathrm{g}^{-1}$ of $E$ - $\beta$-carotene) were found in peeled C. moschata (Baianinha cultivar) (AzevedoMeleiro \& Rodriguez-Amaya, 2007; Kandlakunta et al., 2008; Kurz et al., 2008).

Carotenoids have antioxidant activity, but few of them are converted into retinol, the active form of vitamin A (Burns et al., 2003; Rodriguez-Amaya \& Kimura, 2004; Quirós \& Costa, 2006; Dini et al., 2013). Of the $600+$ carotenoids with pro-vitamin A activity, the most common are $\alpha$ - and $\beta$-carotene. These carotenoids are susceptible to degradation (isomerization and oxidation) during cooking.

In the low-income areas of Northeast Brazil, there is a high prevalence of night blindness caused by vitamin A deficiency. Infants, school-age children, and pregnant women are particularly vulnerable.
Sweet pumpkin preparations (a traditional dessert dish in Brazil that is offered in the School Feeding Program) may be a way of increasing the consumption of pumpkin with high concentrations of pro-vitamin A. Generally, school-age children prefer and consume sweet foods that contain added sugar as opposed to salted foods (boiled or steamed). Therefore, pumpkins cooked with added sugar and consumed as a small dessert may be a viable option for increasing the pro-vitamin A intake in children.

Vitamin A deficiency (VAD) represents one of the major avoidable public health problems in the world and is one of the most important factors that contribute to the high morbidity and mortality rates among children in developing countries (Tomkins, 2000; Kapil \& Bhavna, 2002).

Vitamin A deficiency is an avoidable cause of blindness worldwide (Underwood \& Arthur, 1996; Gilbert \& Foster, 2001; Kello \& Gilbert, 2003), especially in underdeveloped countries.

Studies have been conducted by Embrapa Coastal Tablelands in Aracaju and in partnership with other Embrapa centers and university researchers to select adequate and promising landrace pumpkins for the formulation of these sweet pumpkin meals. The study of the landrace pumpkins is part of the "Biofortification in Brazil: Breeding Crops for Better Nutrition - BioFORT" project, which is financially supported by the Embrapa Monsanto Research Fund.

1 Centro de Ciências da Saúde - CCS, Faculdade de Farmácia, Universidade Federal do Rio de Janeiro - UFRJ, Rio de Janeiro, RJ, Brasil, e-mail: luciajaeger@gmail.com

${ }^{2}$ Embrapa Agroindústria de Alimentos, Guaratiba, Rio de Janeiro, RJ, Brasil

${ }^{3}$ Escola de Nutrição, Universidade Federal do Estado do Rio de Janeiro - UNIRIO, Rio de Janeiro, RJ, Brasil

${ }^{*}$ Corresponding author 
The aim of this study was to evaluate the total carotenoid, $\alpha$ - and $\beta$-carotene, and 9 and $13-Z$ - $\beta$-carotene isomers in landrace pumpkin samples subjected to different cooking methods.

\section{Materials and methods}

\subsection{Raw material}

Landrace pumpkins (C. moschata) were harvested at Embrapa Coastal Tablelands in Aracaju, Brazil and sent to Rio de Janeiro for the determination of moisture, soluble solids, total carotenoids, $\alpha$ - and $\beta$-carotene, and 9 and $13-Z$ - $\beta$-carotene isomers. All analyses were performed in triplicate.

\subsection{Sample preparation}

Figure 1 shows the landrace pumpkin sample preparations according to the cooking method applied.

\section{Sampling}

Samples of raw landrace pumpkins were peeled and divided into four parts by two longitudinal cuts (from one end to the opposite end), resulting in four sections (Figure 2). From these four sections, the two sections opposite from each other were discarded, and the remaining two sections were used in the cooking experiments. For the analyses, the sections were fragmented and placed in a vertical mixer (IKA - Ultraturrax model T18 basic) to obtain a homogeneous mass.

\section{Cooking methods}

Two landrace pumpkins of C. moschata $(135.0 \pm 0.7 \mathrm{~g})$ were washed, peeled, cut in small pieces, and divided into 4 different groups; the pumpkin pieces were then cooked in boiling water
(2:1 for 4 minutes), steamed cooked (5 minutes), or cooked with a $60 \%$ sucrose solution in $200 \mathrm{~mL}$ of water (for the sweet preparation).

\section{Moisture and soluble solids}

The moisture and soluble solids were determined by gravimetry and refractometry, respectively (Association of Official Analytical Chemists, 2005).

\subsection{Carotenoid extraction and determination}

The total amount of carotenoids in the pumpkin samples was determined using a spectrophotometer (Thermo Scientific Evolution 60) set at $450 \mathrm{~nm}$.

All solvents and chemicals were obtained from commercial sources (Tedia and Merck). The $\alpha$ - and $\beta$-carotene standards were purchased from Sigma-Aldrich (Brazil).

To determine the amount of total carotenoids, $\alpha$ - carotene, $\beta$-carotene, and its $Z$ isomers in the raw and cooked pumpkin samples, approximately $0.300 \mathrm{~g}$ of the samples and $3.0 \mathrm{~g}$ of celite 454 (Tedia, Ohio, USA) were weighed in a mortar on a digital balance (Bel Engineering, model MA0434/05).

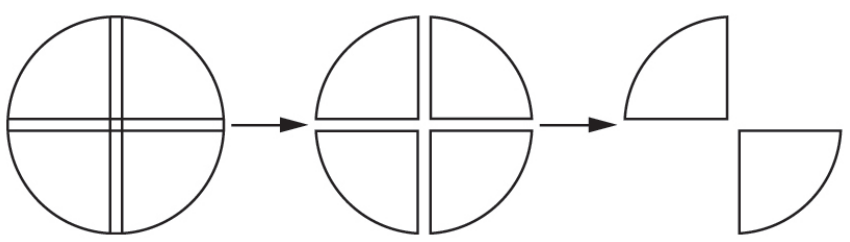

Figure 2. Landrace pumpkins quarterization.

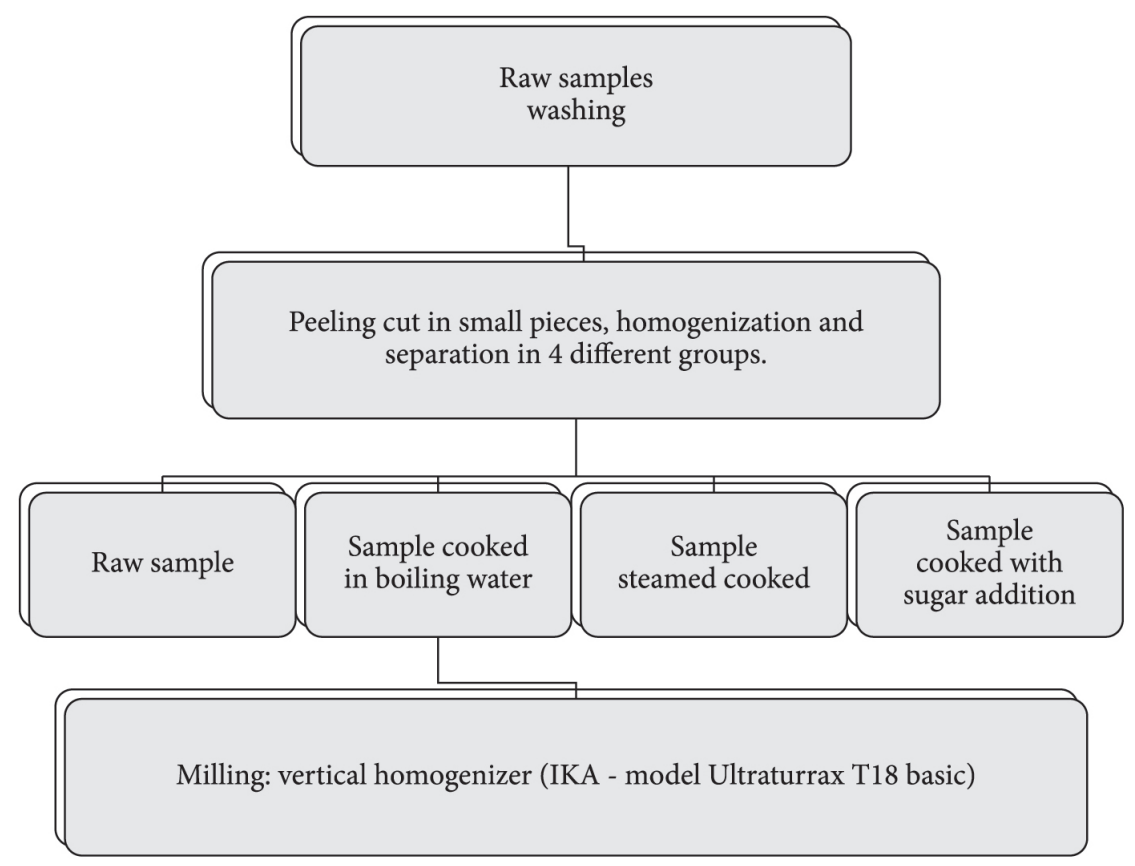

Figure 1. C. moschata landrace preparation. 
For the carotenoid extraction, $25 \mathrm{~mL}$ of acetone was successively added until a paste was obtained. The paste was transferred to a sintered funnel $(5 \mu \mathrm{m})$ coupled to a $250 \mathrm{~mL}$ Buchner flask and filtered under vacuum. This procedure was repeated at least three times until the sample was colorless. The obtained extract was transferred to a $500 \mathrm{~mL}$ separatory funnel containing $40 \mathrm{~mL}$ of petroleum ether. The acetone was removed through the slow addition of ultrapure water (Milli - Q - Millipore) to prevent the formation of emulsion. The aqueous phase was discarded, and this procedure was repeated four times until no residual solvent remained. The extract was then transferred with a funnel to a $50 \mathrm{~mL}$ volumetric flask containing $15 \mathrm{~g}$ of anhydrous sodium sulfate. The final volume was adjusted with petroleum ether, and the samples were analyzed at $450 \mathrm{~nm}$. The total carotenoid content was calculated using the following formula:

Carotenoid content $(\mu \mathrm{g} / \mathrm{g})=\frac{A \times V(m L) \times 10^{4}}{A_{1 \mathrm{~cm}}^{1 \%} \times P(\mathrm{~g})}$

where $\mathrm{A}=$ absorbance; $\mathrm{V}=$ total extract volume; $\mathrm{P}=$ sample weight; and $A_{1 \mathrm{~cm}}^{1 \%}=2592$ (i.e., the $\beta$-carotene extinction coefficient in petroleum ether).

\subsection{Identification and quantification of $\alpha$-carotene, $\beta$-carotene, and $\beta$-carotene isomers}

Alpha-carotene, $\beta$-carotene, and its isomers $(Z)$ were analyzed using a high-performance liquid chromatograph (Waters 2695 - Alliance Model, Milford, USA) with a UV/Visible photodiode array detector that scanned between 350 to $600 \mathrm{~nm}$ using the Empower software. A C30 column (YCM Carotenoid S-3, $4.6 \mathrm{~mm} \times 250 \mathrm{~mm}$ ) was purchased from Waters. The HPLCgrade mobile phase solvents were purchased from Tedia (Rio de Janeiro, RJ, Brazil) and consisted of an 8:2 volumetric ratio of methanol to t-butyl methyl ether. The mobile phase flow rate was $0.8 \mathrm{~mL} / \mathrm{min} ; 25.0 \mu \mathrm{L}$ of an ether extract sample was injected. The temperature was set at $30^{\circ} \mathrm{C}$, and the analysis lasted 60 minutes. All analyses were conducted in triplicate.

For the identification and quantification of $a$-carotene, $\beta$-carotene, and its $Z$ isomers, $2 \mathrm{~mL}$ were removed from the carotenoid extract and dried in an amber flask under flowing nitrogen. The sample was diluted in $100 \mu \mathrm{L}$ of acetone while mixing in a vortex mixer (Genie 2-Scientific Industries) and then transferred to a $2 \mathrm{~mL}$ amber flask for high-performance liquid chromatography (HPLC) analysis.

Although the $\mathrm{Z}$ isomers have lower pro-vitamin $\mathrm{A}$ activity than that of $\beta$-carotene, the isomers may be present in the samples in significant proportions relative to the total carotenoids (Clydesdale et al., 1970; Bauernfeind, 1972; Rodriguez-Amaya \& Kimura, 2004; Ihl et al., 1998; Dutta et al., 2005; Regal et al., 2014).
The content determination of $\alpha$-carotene, $\beta$-carotene, and its $Z$ isomers was performed according to the formula:

$C(\mu / g)=\frac{A_{x} \times C_{s}(\mu / g) \times V(m L)}{A_{s} \times P(g)}$

where $\mathrm{A}_{\mathrm{x}}=$ carotenoid peak area; $\mathrm{C}_{\mathrm{s}}=$ standard concentration; $\mathrm{A}_{\mathrm{s}}=$ standard area; $\mathrm{V}=$ total extract volume and $\mathrm{P}=$ sample weight.

\subsection{Statistical analyses}

The data were analyzed using ANOVA and Kruskal-Wallis test at a significance level of 0.05 . The statistical analyses were performed using the Statistica software version 5.1.

\section{Results and discussion}

\subsection{Moisture and soluble solids}

Table 1 shows the values of moisture and soluble solids in the raw and cooked landrace pumpkins (i.e., boiled, steamed, and cooked with added sugar).

As expected, there were significant differences in the moisture and soluble solid contents $(P<0.05)$ between all pumpkin samples before and after the cooking methods.

The pumpkins cooked with added sugar had the lowest moisture content, followed by the raw, steamed, and boiled samples.

The highest soluble solid content was detected in the samples cooked with added sugar. Significant differences $(P<0.05)$ were found between all pumpkin samples analyzed.

Souza et al. (2011) reported higher moisture values $\left(92 \mathrm{~g} .100 \mathrm{~g}^{-1}\right)$ and lower soluble solids values $\left(9.4 \mathrm{~g} .100 \mathrm{~g}^{-1}\right)$ in raw C. moschata after subjecting the samples to an osmotic dehydration method. Additionally, Molina Filho et al. (2011), who assessed the moisture sorption isotherms in fresh and blanched C. moschata, reported a moisture value of $93.47 \mathrm{~g} .100 \mathrm{~g}^{-1}$.

However, in our study, the soluble solid content in the raw C. moschata was higher than those reported by Russo et al. (2012) in C. maxima (6.6 g.100 g-1) and Abou-Zaid et al. (2012) in pumpkin juice $\left(6 \mathrm{~g} .100 \mathrm{~g}^{-1}\right)$.

Pongjanta et al. (2006) reported moisture and soluble solid contents in fresh pumpkins of 84.32 and $9.27 \mathrm{~g} .100 \mathrm{~g}^{-1}$, respectively, before processing the pumpkin into powder for bakery purposes.

According to Mayor et al. (2006) and Lee \& Lim (2011), the moisture and soluble solid contents in C. pepo pumpkin cultivars purchased from a local market in Spain ranged between

Table 1. Moisture (g.100 $\mathrm{g}^{-1}$ ) and soluble solids ( ${ }^{\circ}$ Brix).

\begin{tabular}{ccccc}
\hline & Raw & Cooked in boiling water & Steamed cooked & Cooked with sugar addition \\
\hline Moisture & $85.29( \pm 0.44)^{\mathrm{a}}$ & $87.96( \pm 0.22)^{\mathrm{b}}$ & $86.59( \pm 0.26)^{\mathrm{c}}$ & $80.43( \pm 0.95)^{\mathrm{d}}$ \\
Soluble solids & $12.13( \pm 0.08)^{\mathrm{a}}$ & $9.27( \pm 0.41)^{\mathrm{b}}$ & $10.77( \pm 0.23)^{\mathrm{c}}$ & $17.08( \pm 0.86)^{\mathrm{d}}$ \\
\hline
\end{tabular}

$\mathrm{SD}=$ Standard Deviation. All analyses were carried out in triplicate. Different uppercase letters in the same line means significant differences $(P<0.05)$ 
Table 2. Contents of total carotenoid, $\alpha$ and $\beta$-carotene, and 9 and $13-Z$ - $\beta$-carotene isomers (in wet basis).

\begin{tabular}{lccrr}
\hline Carotenoids $\left(\mu \mathrm{g} . \mathrm{g}^{-1}\right)$ & Raw Sample & $\begin{array}{c}\text { Cooked in } \\
\text { boiling water }\end{array}$ & $\begin{array}{c}\text { Steamed } \\
\text { cooked }\end{array}$ & $\begin{array}{c}\text { Cooked } \\
\text { with sugar addition }\end{array}$ \\
\hline$\alpha$-carotene & $39.95( \pm 2.26)^{\mathrm{a}}$ & $43.97( \pm 3.51)^{\mathrm{a}, \mathrm{b}}$ & $47.09( \pm 1,87)^{\mathrm{b}}$ & $45.68( \pm 1.38)^{\mathrm{b}}$ \\
$\beta$-carotene & $172.20( \pm 8.16)^{\mathrm{a}}$ & $184.80( \pm 14.91)^{\mathrm{a}, \mathrm{b}}$ & $202.00( \pm 12.74)^{\mathrm{b}}$ & $168.80( \pm 8.11)^{\mathrm{a}, \mathrm{c}}$ \\
9-- $\beta$-carotene & $0.86( \pm 0.23)^{\mathrm{a}}$ & $0.77( \pm 0,29)^{\mathrm{a}}$ & $1.24( \pm 0.81)^{\mathrm{a}}$ & $2.03( \pm 1,02)^{\mathrm{a}}$ \\
$\mathbf{1 3 - - ~} \beta$-carotene & $3.64( \pm 1.54)^{\mathrm{a}}$ & $6.80( \pm 1.88)^{\mathrm{a}, \mathrm{b}}$ & $8.23( \pm 0.66)^{\mathrm{b}}$ & $8.31( \pm 0.37)^{\mathrm{b}}$ \\
Total carotenoids & $236.10( \pm 6.81)^{\mathrm{a}}$ & $258.50( \pm 11.78)^{\mathrm{b}}$ & $280.77( \pm 12.58)^{\mathrm{c}}$ & $251.90( \pm 5.16)^{\mathrm{b}}$ \\
\hline
\end{tabular}

$\mathrm{SD}=$ standard deviation. All analyzes were carried out in triplicate. Different uppercase letters in the same line means significant differences $(P<0.05)$.

95-97 g. $100 \mathrm{~g}^{-1}$ (wet basis) and 2-4 g. $100 \mathrm{~g}^{-1}$, respectively. AbouZaid et al. (2012) reported $84.6 \mathrm{~g} .100 \mathrm{~g}^{-1}$ in pumpkin puree.

\subsection{Carotenoids in raw and cooked pumpkins}

Table 2 shows the total carotenoid, $\alpha$ - and $\beta$-carotene, and 9 and $13-Z-\beta$-carotene isomers found in the raw pumpkins and after the different home-cooking methods.

The raw samples contained $236.10 \mu \mathrm{g} . \mathrm{g}^{-1}, 172.20 \mu \mathrm{g} . \mathrm{g}^{-1}$, $39.95 \mu \mathrm{g} \cdot \mathrm{g}^{-1}, 3.64 \mu \mathrm{g} \cdot \mathrm{g}^{-1}$, and $0.86 \mu \mathrm{g} \cdot \mathrm{g}^{-1}$ of total carotenoid, $\beta$-carotene, $\alpha$-carotene, $13-Z$ - $\beta$-carotene, and 9-Z- $\beta$-carotene isomers, respectively. Aguilar-Gutiérrez (2009) reported that the total carotenoids in C. moschata ranged from 171.9 to $461.9 \mu \mathrm{g} . \mathrm{g}^{-1}$, and Ramos et al. (2009) reported values ranging from 100.50 to $365.40 \mu \mathrm{g} \cdot \mathrm{g}^{-1}$. These samples had higher contents of total carotenoids than those of the samples in our study.

Other important sources of $\beta$-carotene have been studied. Donado-Pestana et al. (2012) reported that raw biofortified orange-fleshed sweet potatoes (CNPH 1194 cultivar) contained $128.5 \mu \mathrm{g} . \mathrm{g}^{-1}, 9.6 \mu \mathrm{g} . \mathrm{g}^{-1}, 5.8 \mu \mathrm{g} . \mathrm{g}^{-1}$ of all-E- $\beta$-carotene, and 13 - and 9 - $Z$ - $\beta$-carotene isomers, respectively. These values are lower than those detected in the raw landrace pumpkins of our study.

According to Van Jaarsveld et al. (2006), although the $\mathrm{Z}$-isomers have lower pro-vitamin A activity, the pumpkin samples have high amounts of $\beta$-carotene in the $Z$ configuration. On the other hand, in the present study, the $13-\mathrm{Z}$ isomer increased after all cooking methods applied.

Previous studies have shown that heat treatment improves the bioavailability of carotenoids. Cooking practices break down the food matrices and loosen the carotene-binding fibers, leading to nutrient loss; however, the bioavailability and sometimes even the carotene content can increase (Adams \& Erdman, 1988; Sungpuag et al., 1999, Fernández-García et al., 2012).

According to De Pee (1996), carotene from fruits, tubers, and pulpy vegetables, such as pumpkin, are considered to be better absorbed than those from dark green leafy vegetables.

The $\alpha$-carotene content varied from $39.95 \mu \mathrm{g} . \mathrm{g}$ in the raw pumpkin samples to $47.09 \mu \mathrm{g} \cdot \mathrm{g}^{-1}$ in the steamed samples $(P<0.05)$. However, there were no significant differences between the pumpkin samples cooked in boiling water, steamed, or cooked with added sugar.

The $\beta$-carotene content in the steamed sample was $202.00 \mu \mathrm{g} . \mathrm{g}^{-1}$, which was significantly different $(P<0.05)$ from the contents in the other samples. In this study, the $\beta$-carotene content was higher than those reported by Ramos et al. (2009) (37.6-63.22 $\left.\mu \mathrm{g} . \mathrm{g}^{-1}\right)$.

The $9-Z$ - $\beta$-carotene isomer content did not differ significantly $(P<0.05)$ between all pumpkin samples; it ranged from $0.77 \mu \mathrm{g} . \mathrm{g}^{-1}$ in the steamed cooked sample to $2.03 \mu \mathrm{g} \cdot \mathrm{g}^{-1}$, in the sample cooked with added sugar.

The 13-Z- $\beta$-carotene isomer content in the cooked sample was significantly different $(P<0.05)$ from that in the raw sample.

The steamed samples had the highest contents of total carotenoids, $\beta$-carotene, and $\alpha$-carotene.

Additionally, the pumpkin cooked with added sugar had the highest contents of 13 - and 9-Z- $\beta$-carotene.

This result is likely caused by moisture losses during cooking. Another reason could be differences in the biological structures of the landrace samples. Azizah et al. (2009) observed $\beta$-carotene retention greater than $100 \%$ after cooking pumpkins (C. moschata) in boiling water. The authors found a 2 - to 4 -fold increase in the $\beta$-carotene content in the pumpkins after cooking for 2, 4, and 6 minutes.

Generally, the processing of vegetables results in a breakdown of the cellulose plant cell structure and thus improves the bioavailability of carotenoids (Van Het Hof et al., 2000). High contents of total carotenoids were reported by Bengtsson et al. $(2008,2009)$ in boiled $\left(570.60 \mu \mathrm{g} . \mathrm{g}^{-1}\right)$ and steamed orangefleshed sweet potatoes $\left(682.40 \mu \mathrm{g} \cdot \mathrm{g}^{-1}\right)$.

\section{Conclusion}

High contents of $\alpha$ - and $\beta$-carotene were found in all $C$. moschata pumpkin landraces evaluated. The carotenoids were more bioavailable after the heat treatments. The total carotenoid and $\beta$-carotene isomers contents increased according to the cooking methods applied. Pumpkin consumption in Northeast Brazil could be more aggressively promoted to minimize vitamin A deficiency in this geographic area. The results of this study are promising, considering that $\beta$-carotene has $100 \%$ pro-vitamin A activity. More studies must be carried out with other $C$. moschata pumpkin landraces to identify pumpkins with higher $\beta$-carotene contents.

\section{Acknowledgments}

The authors would like to thank HarvestPlus, the Embrapa - Monsanto Research Fund, for supporting the BioFORT project, as well as FAPERJ and CAPES, for providing student scholarships. 


\section{References}

Abou-Zaid, A. A. M., Nadir, A. S., \& Mostafa, T. R. (2012). Studies on sheets properties made from juice and puree of pumpkin and some other fruit blends. Journal of Applied Sciences Research, 8(5), 26322639.

Adams, C. E., \& Erdman, J. W. (1988). Effects of home food preparation practices on nutrient content of foods. In E. Karmas \& R. Harris (Eds.), Nutritional evaluation of food processing (pp. 557-595), New York: AVI Publ. http://dx.doi.org/10.1007/978-94-011-7030-7_21

Aguilar-Gutiérrez, F. (2009). Caracterización química, física, funcional y nutrimental dela calabaza cehualc (Cucurbita moschata D.), cv Cehualca integral (Master's thesis). Universidad Autónoma de Sinaloa, México.

Association of Official Analytical Chemists - AOAC. (2005). Official Methods of Analysis of AOAC International (18th ed.). Gaithersburg: AOAC.

Azevedo-Meleiro, C. H., \& Rodriguez-Amaya, D. B. (2007). Quantitative and qualitative differences in carotenoids composition among Cucurbita moschata, Cucurbita maxima and Cucurbita pepo. Journal of Agricultural and Food Chemistry, 55(10), 4027-4033. PMid:17444652. http://dx.doi.org/10.1021/jf063413d

Azizah, A. H., Wee, K. C., Azizah, O., \& Azizah, M. (2009). Effect of boiling and stir frying on total phenolics, carotenoids and radical scavenging activity of pumpkin (Cucurbita moschata). International Food Research Journal, 16, 45-51.

Bauernfeind, J. C. (1972). Carotenoid vitamin A precursors and analogs in foods and feeds. Journal of Agricultural and Food Chemistry, 20(3), 456-473. PMid:4562921. http://dx.doi. org/10.1021/jf60181a003

Bengtsson, A., Namutebi, A., Larson-Alminger, M., \& Svanberg, U. (2008). Effects of various traditional processing methods on the all-trans-b-carotene content of orange sweet potato. Journal of Food Composition and Analysis, 21(2), 134-143. http://dx.doi. org/10.1016/j.jfca.2007.09.006

Bengtsson, A., Larsson-Alminger, M., \& Svanberg, U. (2009). In vitro bioaccessibility of $\beta$-carotene from heat-processed orange-fleshed sweet potato. Journal of Agricultural and Food Chemistry, 57(20), 9693-9698. PMid:19807125. http://dx.doi. org/10.1021/jf901692r

Boiteux, L. S., Nascimento, W. M., Fonseca, M. E. N., Lana, M. M., Reis, A., Mendonça, J. L., Lopes, J. F., \& Reifschneider, F. J. B. (2007). 'Brasileirinha': cultivar de abóbora (Cucurbita moschata) de frutos bicolores com valor ornamental e aptidão para consumo verde. Horticultura Brasileira, 25(1), 103-106. http://dx.doi.org/10.1590/ S0102- 05362007000100020

Burns, J., Fraser, P. D., \& Bramley, P. M. (2003). Identification and quantification of carotenoids, tocopherols and chlorophylls in commonly consumed fruits and vegetables. Phytochemistry, 62(6), 939-947. http://dx.doi.org/10.1016/S00319422(02)00710-0

Clydesdale, F. M., Fleischman, D. L., \& Franz, F. L. (1970). Maintenance of color in processed green vegetables. Journal of Food Product Development, 4, 127-130.

Donado-Pestana, C. M., Salgado, J. M., Rios, A. O., Santos, P. R., \& Jablonski, A. (2012). Stability of carotenoids, total phenolics and in vitro antioxidant capacity in the thermal processing of orange-fleshed sweet potato (Ipomoea batatas Lam.) cultivars grown in Brazil. Plant Foods Human Nutrition, 67(3), 262-227. PMid:22802046. http://dx.doi.org/10.1007/s11130-012-0298-9
De Pee, S. (1996). Food-based approaches for controlling vitamin A deficiency: studies in breastfeeding women in Indonesia (Doctoral thesis). University of Wageningen, The Netherlands.

Dini, I., Tenore, G. C., \& Dini, A. (2013). Effect of industrial and domestic processing on antioxidant properties of pumpkin pulp. LWT - Food Science and Technology, 53(1), 382-385. http://dx.doi. org/10.1016/j.lwt.2013.01.005

Dutta, D., Raychaudhuri, U., \& Chahraborty, R. (2005). Retention of b-carotene in frozen carrots under varying conditions of temperature and time of storage. African Journal of Biotechnology, 4(Suppl. 1), 103-104.

Fernández-García, E., Carvajal-Lérida, I., Jarén-Galán, M., GarridoFernández, J., Pérez-Gálvez, A., \& Hornero-Méndez, D. (2012). Carotenoids bioavailability from foods: from plant pigments to efficient biological activities. Food Research International, 46(2), 438450. http://dx.doi.org/10.1016/j.foodres.2011.06.007

Gilbert, C., \& Foster, A. (2001). Childhood blindness in the context of VISION 2020: the right to sight. Bulletin of the World Health Organization, 79(3), 227-232. PMid:11285667 PMCid:PMC2566382.

Ihl, M., Monslaves, M., \& Bifani, V. Chlorophylase inactivation as a measure of blanching efficiency and color retention of artichokes (Cynara scolyus L.). LWT - Food Science and Technology, 31(1), 51$56,1998$.

Kapil, U., \& Bhavna, M. (2002). Adverse effects of poor micronutrients status during childhood and adolescence. Nutrition Review, 60(2), S84-S90. http://dx.doi.org/10.1301/00296640260130803

Kello, A. B., \& Gilbert, C. (2003). Causes of severe visual impairment and blindness in chidren in schools for the blind in the Ethiopia. British Journal of Ophthalmology, 87(5), 526-530. PMid:12714383 PMCid:PMC1771673. http://dx.doi.org/10.1136/bjo.87.5.526

Juna, H., Leeb, C. H., Songc, G. S., \& Kima, Y. S. (2006). Characterization of the pectic polysaccharides from pumpkin peel. LWT- Food Science and Technology, 39(5), 554-561. http://dx.doi.org/10.1016/j. lwt.2005.03.004

Kandlakunta, B., Rajendran, A., \& Thingnganing, L. (2008). Carotene content of some common (cereals, pulses, vegetables, spices and condiments) and unconventional sources of plant origin. Food Chemistry, 106(1), 85-89. http://dx.doi.org/10.1016/j. foodchem.2007.05.071

Kurz, C., Carle, R., \& Schieber, A. (2008). HPLC-DAD-MSn characterization of carotenoids from apricots and pumpkins for the evaluation of fruit product authenticity. Food Chemistry, 110(2), 522530. http://dx.doi.org/10.1016/j.foodchem.2008.02.022

Lee, J. S., \& Lim, L. S. (2011). Osmo-dehydration pretreatment for drying of pumpkin slice. International Food Research Journal, 18(4), 1223-1230.

Mayor, L., Moreira, R., Chenlo, F., \& Sereno, A. M. (2006). Kinetics of osmotic dehydration of pumpkin with sodium chloride solutions. Journal of Food Engineering, 74(2), 253-262. http://dx.doi. org/10.1016/j.jfoodeng.2005.03.003

Mínguez-Mosquera, M. I., Hornero-Méndez, D., \& Pérez-Gálvez, A. (2002). Carotenoids and provitamin A in functional foods. In W. J. Hurst (Ed.), Methods of analysis for functional foods and nutraceuticals (Vol. 1, pp. 101-158). Washington: CRC Press. http:// dx.doi.org/10.1201/9781420014679.ch3

Molina Filho, L., Gonçalves, A. K. R., Mauro, M. A., \& Frascareli, E. C. (2011). Moisture sorption isotherms of fresh and blanched pumpkin (Cucurbita moschata). Ciência e Tecnologia de Alimentos, 31(3), p. 714-722. http://dx.doi.org/10.1590/S0101-20612011000300025 
Pongjanta, J., Naulbunrang, A., Kawngdang, S., Manon, T., \& Thepjaikat, T. (2006). Utilization of pumpkin powder in bakery products. Songklanakarin Journal of Science and Technolology, 28(1), 71-79.

Quirós, A. R. B., \& Costa, H. S. (2006). Analysis of carotenoids in vegetable and plasma samples: a review. Journal of Food and Composition Analysis, 19(2-3), 97-111. http://dx.doi.org/10.1016/j. jfca.2005.04.004

Ramos, S. R. R., Carvalho, H. W. L., Oliveira, I. R., Anjos. J. L., Queiróz. M. A., Lima, M. A. C., Nutti, M. R., Kimura, M., Dias, R. C. S., \& Borges, R. M. E. (2009). Identificação de acessos locais de abóbora com elevados teores de carotenóides totais e características agronômicas e comerciais. In Proceedings of the 3th Biofortification in Brazil Annual Meeting, Sergipe, Brazil.

Regal, P., Amorim-Carrilho, K. T., Cepeda, A., \& Fente, C. (2014). Review of methods for analysis of carotenoids. TrAC Trends in Analytical Chemistry, 56, 49-73. http://dx.doi.org/10.1016/j. trac.2013.12.011

Rodriguez-Amaya, D. B., \& Kimura, M. (2004). HarvestPlus handbook for carotenoid analysis (HarvestPlus Technical Monograph 2). Washington: HarvestPlus.

Rodriguez-Amaya, D. B., Kimura, M., Godoy, H. T., \& Amaya-Farfan, J. (2008). Updated Brazilian database on food carotenoids: factors affecting carotenoids composition. Journal of Food Composition and Analysis, 21(6), 445-463. http://dx.doi.org/10.1016/j. jfca.2008.04.001

Russo, V. C., Daiuto, E. R., Santos, B. L., Lozano, M. G., Vieites, R. L., \& Vieira, M. R. S. (2012). Quality of fresh-cut squash stored in active modified atmosphere. Ciências Agrárias, 33(3), 1071-1084. http:// dx.doi.org/10.5433/1679-0359.2012v33n3p1071

Silva, S. R., \& Mercadante, A. Z. (2002). Carotenoid composition of fresh yellow passion fruit (Passiflora edulis). Food Science and Technology, 22(3), 254-258.

Souza, D. S., Costa, I. P., Pimentel, J. D. R., Coutinho, J. P., \& Silva, A. A. L. (2011). Study of drying kinetics of cooked pumpkin in different sizes. In Proceedings of the 5th Congresso Latino Americano and 11th Congresso Brasileiro de Higienistas de Alimentos, Salvador, Brazil.

Sungpuag, P., Tangehitpianvit, S., Chittchang, U., \& Wasantwisut, E. (1999). Retinol and beta carotene content of indigenous raw and home-prepared foods in Northern Thailand. Food Chemistry, 64(2), 162-167. http://dx.doi.org/10.1016/S03088146(98)00154-X

Tomkins, A. Malnutrition, morbidity and mortality in children and their mothers. Proceedings of Nutrition Society, 59(1), 135-146, 2000. PMid:10828183. http://dx.doi.org/10.1017/S0029665100000161

Underwood, B. A., \& Arthur, P. The contribution of vitamin A to public health. The FASEB Journal, 10(9), 1040-1048, 1996. PMid:8801165.

Van Jaarsveld, P. J., Marais, D. W., Harmse, E., Nestel, P., \& RodriguezAmaya, D. B. (2006). Retention of b-carotene in boiled, mashed orange-fleshed sweet potato. Journal of Food Composition and Analysis, 19(4), 321-329. http://dx.doi.org/10.1016/j. jfca.2004.10.007

Van Het Hof, K. H., West, C. E., Weatstrate, J. A., \& Hautvast, J. G. A. J. (2000). Dietary factors that affect the bioavailability of carotenoides. Journal of Nutrition, 130(3), 503-506. 